\title{
Improving Students' Learning Results Through the SQ4R Learning Model Approach
}

\author{
Iswan $^{1}$, Herwina ${ }^{1}$, Teguh Ridka Fitrianto ${ }^{2}$ \\ ${ }^{1}$ Faculty of Education, Muhammadiyah University of Jakarta, Jakarta, Indonesia \\ ${ }^{2}$ Teacher Elemtery Laboratorium School FIP-UMJ,Kota Tangerang Selatan, Indonesia
}

\section{Email address:}

iswanfipumj@gmail.com (Iswan)

\section{To cite this article:}

Iswan, Herwina, Teguh Ridka Fitrianto. Improving Students' Learning Results Through the SQ4R Learning Model Approach. Education Journal. Vol. 8, No. 6, 2019, pp. 239-243. doi: 10.11648/j.edu.20190806.11

Received: July 31, 2019; Accepted: August 26, 2019; Published: September 16, 2019

\begin{abstract}
The results of observations and evaluations of students in $6^{\text {th }}$ grade of Semester I, mathematics learning in 2017/2018 learning year most of the scores are still below the Minimum Completion Criticism of mathematics learning by 70 . This is evidenced by the data of 17 students, 8 students or (47.06\%) scored above the Minimum Completion Criticism, while 9 students or (52.94\%) scored below the Minimum Completion Criticism. Based on this statement, the researcher set a solution to improve mathematics learning outcomes by using the approach of the learning model Survey, Question, Read, Recite, Reflect, and Review (SQ4R). The SQ4R model is a learning model that provides curiosity and can encourage processing in depth and breadth. The formulation of the research problem is how can student learning outcomes on mathematics subjects be improved through the use of learning models (SQ4R)? How do you implement the Survey learning model (SQ4R) can improve mathematics learning outcomes for $6^{\text {th }}$ grade, students of primary school in SD Lab. School FIP-UMJ? The study was conducted in 2 cycles. Each cycle consists of 4 stages. They are planning, implementation, observation, and reflection. The research subjects were 17 students. Data collection techniques was used test material techniques. Minimum Completion Criticism score, classical learning completeness is at least $85 \%$, and individual completeness is at least 70 . Percentage of completeness in cycle I is $82.35 \%$, and cycle II $88.24 \%$, implementation of SQ4R model can improve Mathematics learning outcomes.
\end{abstract}

Keywords: Improving Student Learning Results, Through the SQ4R, Learning Model Approach

\section{Introduction}

Based on the regulation of The Ministry of Education and Culture Number 57 in 2014 concerning the basic framework of the elementary curriculum that the Indonesia's curriculum in 2013 uses "integrative thematic learning" from 1st grade to $6^{\text {th }}$ grade. Thematic learning is learning that uses themes to associate several subjects so as to provide meaningful experiences of the students. Refer to Trianto (2010) that cited by Esah, et all (2013), the advantages of thematic learning are: 1) students easily focus on a particular theme, 2) students are able to learn knowledge and develop various basic competencies in many subjects at the same theme, 3) understanding the subject matter more deeply and impressively, 4) basic competencies can be developed better by linking other subjects with personal experiences of students, 5) students are better able to feel the benefits and meaning of learning because the material is presented in the context of a clear theme, 6) students are more passionate to learn because they can communicate in real situations to develop an abilities in the subjects taught, while learning other subjects, and; 7) teachers can save time because the subjects presented can be prepared at once [1].

Thematic learning places more emphasis on student involvement in the learning process. The students can gain direct experience and they are trained to be able to find out the various knowledge learned for themselves. Through direct experience, students can understand the concepts that they learn and combine them with other concepts that have been understood. Therefore, thematic learning emphasizes the application of the concept of learning while doing something. As previously explained, thematic learning is learning that uses 
themes to link subjects. One of the subjects that can be used as thematic subjects is mathematics. Esu (2012) cited by Okoro and Okoro at the International Journal of Education, Learning and Development (2016) explained that thematic instruction is based on the idea that people acquire knowledge. There are 2 steps to select a integrate a theme of learning objectives. First, choosing a theme that connected to the student's everyday life. Second, Designing the integrated curriculum by organize learning objectives of process skills and content knowledge in area of theme as well. [2]

The various efforts made by the Ministry of National Education have not achieved in a satisfactory results. Various international assessment results, showing the ability of Indonesian students, are still in a low rank, especially related to abilities in mathematics, natural sciences, reading ability, economic competitiveness, and readiness for future survival. At the beginning of December 2015, an organization under the Organization of Economic Cooperation and Development (OECD) called the Program for International Student Assessment (PISA), had conducted a survey on the education system, and the abilities of school students. Surveys are held every 3 years. In 2015, PISA surveyed aproximately 540.000 students completed the assessment, representing about 29 million 15-year-olds in the schools of the 72 participating countries and economies, that representing $80 \%$ of the global economy in the world. The results of the new survey were published by the PISA on education and the ability of school students reported by the OECD stated that Indonesia's ranking of education, especially in the fields of mathematics, science, and reading, was ranked $62^{\text {nd }}$ out of 72 countries, increase from 68 in 2012. The average reading score is 403, increase from 396 in 2012. [3] On the other perspective, the release of the results of the last Progress in the International Reading Literacy Study (PIRLS) survey on international reading competences. There are 49 countries as a representastive (sample) that approximately 4,000 students from 150-200 schools participated. Tt have aproximatley 325,000 students participated in PIRLS 2011. Indonesia was ranked $41^{\text {st }}$ out of 45 countries in 2011. [4]. Unfortunately, in next survay (2016), Indonesia was not included as sample of country's reprentative of PIRLS of 72 country's representative of around the world.

Regarding to the PISA and PIRLS data publication above, teacher or school in Indonesia have to improve learning process by strategy and method implementation for enhancing student reading competences. The strategy or method that have to adopt on implementing learning process are SQ4R learning method its abbreviation of Survey, Question, Read, Reflect, Recite, Review. SQ4R can improve learning outcomes because it is effective in helping students memorize memories, information from reading. The level of student mastery of the material taught can be seen from student learning outcomes after taking one subject. These problems also occur in learning mathematics in $6^{\text {th }}$ grade at SD Lab. School FIP-UMJ.

Based on the results of observations and initial reflections with the collaboration team conducted in the first semester of the 2018/2019 academic year that mathematics learning is still not optimal. Lack of curiosity and lack of student motivation in reading. Reading is subjct that is less desirable and considered boring by students, so that in thinking students are less critical, active, in learning, as well as in mathematics learning, the material learned by students can master by frequently practicing solving problems.

This is supported by data from the results of observation and evaluation of mathematics subjects of student in $6^{\text {th }}$ grade of Semester I. In 2018/2019 academic year, most of which are still below the Minimum Completion Criticism (MCC), which is 70 . This is evidenced by data from 17 students as many as $47.06 \%$, get a score above MCC while 9 students or, $52.94 \%$ get a score under MCC. Looking at the data on Mathematics learning outcomes. It is necessary to improve mathematics learning outcomes. The researcher and the collaboration team set an alternative action using the SQ4R model, because the learning steps of the SQ4R model are very suitable to be applied to mathematics learning. In International Journal of Instruction, Epcaca (2016) cited by Basar and Gurbuz (2017) explained that SQ4R is a strategy especially designed for the use in explanatory and descriptive texts. [6] Therefor, Khusniyah, Rasyid, and Lustyantie conducted reseach on "Improving English Reading Comprehension Ability through SQ4R explained that SQ3R improve rading comprehension in English. [7]

The learning model (SQ4R) is a survey learning model or observe: Question or make questions from reading, Read or read, Reflect or provide examples, Recite, is considering the answers given and reviewing that is how to thoroughly review. Based on the description of the background above, the researcher will examine in depth through classroom action research.

\section{Problem of the Research}

a. How to apply the SQ4R learning model to $6^{\text {th }}$ grade of elementary school students at SD Lab. School FIP-UMJ?

b. How to improve mathematics learning outcomes in $6^{\text {th }}$ grade of elementary school students, through the approach of the SQ4R learning model?

\section{Objective of the Research}

a. To find out then how to apply the SQ4R learning model to $6^{\text {th }}$ grade of students at SD Lab. School UMJ.

b. To find out then how to improve mathematics learning outcomes in $6^{\text {th }}$ grade of students at SD Lab. School FIP-UMJ through the approach of the SQ4R learning model. 


\section{Research Method}

The research method used is Classroom Action Research (CAR). The reseach is a study by looking at learning activities that are given actions that are deliberately raised in a class. The aim is to solve problems or improve the quality of learning in that class [8]. The implementation of this study follows the stages of classroom action research, where the implementation of actions consists of several cycles. Each cycle consists of 4 stages in recycling, they are action planning, action, observation, and reflection. The procedure is carried out repeatedly until the expected improvement or improvement is achieved, as according to the Figure 1. [9]

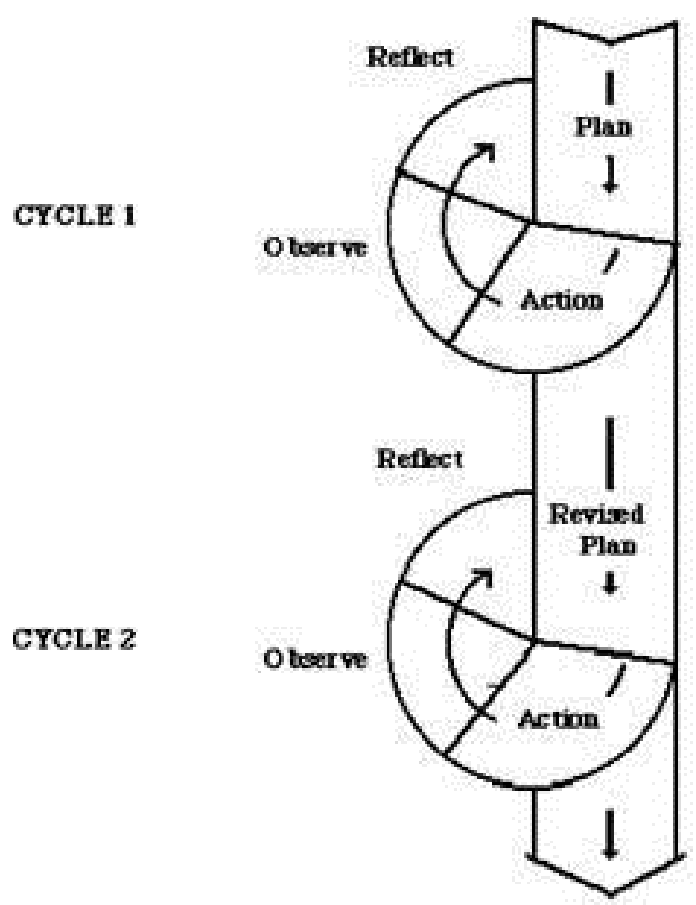

Figure 1. The Cycles of Classroom Action Research.

The scientific approach to the SQ4R learning model can improve learning outcomes in $6^{\text {th }}$ grade at SD Lab. School FIP UMJ. Learning outcomes indicators for $6^{\text {th }}$ grade at SD Lab. School FIP-UMJ students in mathematics learning through the SQ4R achieve classical completeness of at least $85 \%$ with "Kriteria Ketuntasan Minimum (KKM)" or "The Minimum Completion Criteria" at $\geq 70$.

Shoimin (2014) explained the SQ4R learning model includes $6^{\text {th }}$ grade six stages of activity, they are: (1) Survey, preliminary research, at this stage, the reader begins to examine, review, explore with a flash to find chapter titles, sub-chapters, and caption of the material to be delivered in detail, and in accordance with needs; (2) Question (ask), after conducting a survey, some questions may be found; (3) Read (read), this section can be run efficiently and effectively if students really use the list of questions, namely learning and practicing with the intention of finding answers to questions (4) Recite, retell in their own words; (5) Reflect, reflect activity, namely personal experience and critical thinking; (6) Review, review, briefly in the review phase, testing or reviewing the completeness, reiterating what we have done in the reflect step. If there are shortcomings, we complete it, and if there is a mistake, we must correct it. [10]

The SQ4R learning model is very suitable to be applied in mathematics learning in elementary schools, but in reality in its application, in learning research using SQ4R. There are still many obstacles as follows: (1) students who do not master the material, do not carry out the Question stage, besides that it requires direction from the teacher so students can take part in the Question stage; (2) the teacher must understand correctly the steps of the SQ4R learning model; (3) require varied exercises but still in one theme and one discussion; (4) the conditioning of students must run well, so that the learning model SQ4R can run optimally.

\section{Findings Research and Discussion}

Classroom Action Research (CAR) includes two cycles consisting of cycle I and cycle II. Each cycle consists of two meetings and consists of several stages, namely the stages of planning, action, observation, and reflection. In the second cycle the steps carried out were improvements in the previous cycle. The results obtained in this study consisted of test data in the form of student learning outcomes obtained through evaluation tests after doing mathematics learning through the SQ4R learning models.

Both cycles are used to determine the improvement of student learning outcomes with the SQ4R learning model, on the mathematical content of class VI students at SD Lab. School FIP-UMJ. Data obtained before and after the action shows an increase in student learning outcomes indicated by the test results obtained. Before the implementation of the SQ4R learning model, in mathematics learning, there are 8 students or $47.06 \%$ were completed and 9 students or $52.94 \%$ were not completed. After the application of the SQ4R learning model, in mathematics learning in the first and second cycles it was found that student learning outcomes increased.

The results of the first cycle test were obtained by 14 students, or $82.35 \%$ completed and 3 students, or $17.65 \%$ were not completed. Based on these data, it can be said that there was an increase in the completeness of student learning outcomes by $32.69 \%$ in cycle I. Then the results of the cycle II test showed 15 students, or $88.24 \%$ completed and 2 students, or $11.76 \%$ were incomplete.

Based on these results, it can be said that there was an increase in the completeness of student learning outcomes by $5.91 \%$ compared to the pre cycle and at $17.65 \%$ compared to the first cycle. Based on these data, it can be seen that there was an increase in the percentage of students who had minimal learning outcomes in the cycle I, and cycle II. There is an increase that occurs in students who have reached $88.24 \%$ of students have completed and exceed $85 \%$ indicator of success, it is stated that the improvement of this learning has been successful. Learning model of SQ4R. This can also increase learning motivation and increase student participation and activity that takes 
place in the classroom during learning. The results of preliminary observations, cycle I and cycle II then carried out data analysis as a form of testing the hypothesis of action before using the SQ4R model, and after using the SQ4R learning model.

\subsection{Pre Cycle Data Analysis}

The results of the pre-cycle values, it is known that the achievement value of completeness of student learning outcomes in mathematics learning is still not optimal, where most students have not reached the criteria teaching minimum (CTM), which has been set by the school. A total of 9 students, or $52.94 \%$ have not yet reached target. Students who experience mastery learning only 8 students from 17 students, or equal to $47.06 \%$. The class average obtained is also still low at 74.18.

Based on the problems that the researcher has described above, the researcher and team of collaborators carried out classroom action research by applying the Survey Question, Read, Recite, Reflect, Review (SQ4R) learning model, in $6^{\text {th }}$ grade of SD Lab. School FIP-UMJ, to resolve these problems.

\subsection{One Cycle Data Analysis}

Student learning outcomes in the first cycle are the results of individual written tests in the form of multiple choices with a number of 10 questions, a short form of 5 questions, and 5 questions in the mathematics lesson. The number of students taking the test in the first cycle amounted to 17 students.

Based on Figure 2 learning outcomes aspects of student knowledge cycle I obtained that $82.35 \%$ of students have experienced mastery learning in mathematics learning. The average grade obtained is 79.47. Individually the lowest score of students is 54, while the highest score of 100 , of 17 students, 14 students or $82.35 \%$ is complete, while 3 students or $17.65 \%$ are declared incomplete, because they get a score below the minimum completeness criteria (CTM) of 70 . Percentage Student completeness in cycle one can be illustrated through the diagram below:

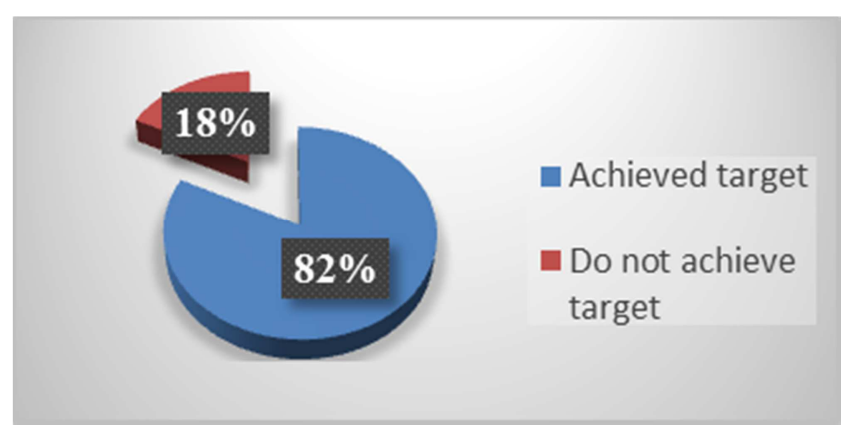

Figure 2. Percentage of Completion of Knowledge Aspects of Student Cycle I.

Based on the explanation that has been described, it can be seen that the learning outcomes in mathematics learning through the SQ4R model, in the first cycle have not yet achieved the specified success indicators. Students' classical learning completeness has not reached the percentage that has been determined by the indicators of success, at least $85 \%$ of student experience mastery learning. As for in this first cycle, the completeness of student learning in classical only reached $82.35 \%$ so that the researcher will proceed to cycle II.

\subsection{Cycle Two Data Analysis}

Learning outcomes aspects of students' knowledge in the second cycle can be seen from the results of individual written tests in the form of multiple choices with multiple choices with a number of 10 questions, a short form of 5 questions, and 5 questions in the mathematics lesson.

The number of students taking the cycle II test totaled 18 students. Based on Figure 3 learning outcomes aspects of students' knowledge cycle I obtained that $82.35 \%$ of students have experienced mastery learning in mathematics learning. The class average value obtained is 79.47 . Individually the lowest score of students is 54, while the highest score is 100 , out of 17 students, 15 students or $88.24 \%$ experience completeness, while 2 students or $11.76 \%$ are declared incomplete because they get a score below CTM of 70 . Percentage of student completeness cycle one can be illustrated through the diagram below:

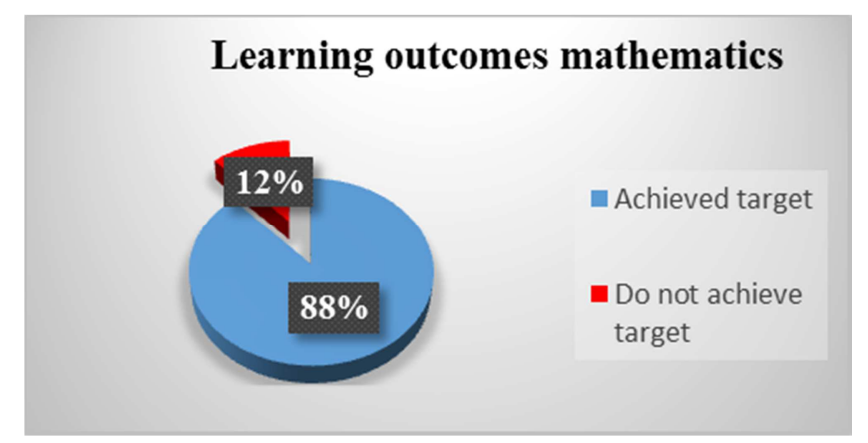

Figure 3. Percentage of Completion of Knowledge Aspects of Student Cycle II.

Learning outcomes obtained in mathematics, through the SQ4R model of the second cycle have reached the determined success indicators. Classical learning completeness of students has reached the percentage that has been determined on the indicator of success. Student learning outcomes have exceeded $85 \%$. Students experience learning completeness of $88.24 \%$ the achievement of learning outcomes in the second cycle. The research has been completed. Improved learning outcomes aspects of student knowledge in mathematics learning through the SQ4R learning model in cycles one and two can be seen in the diagram as follows: 


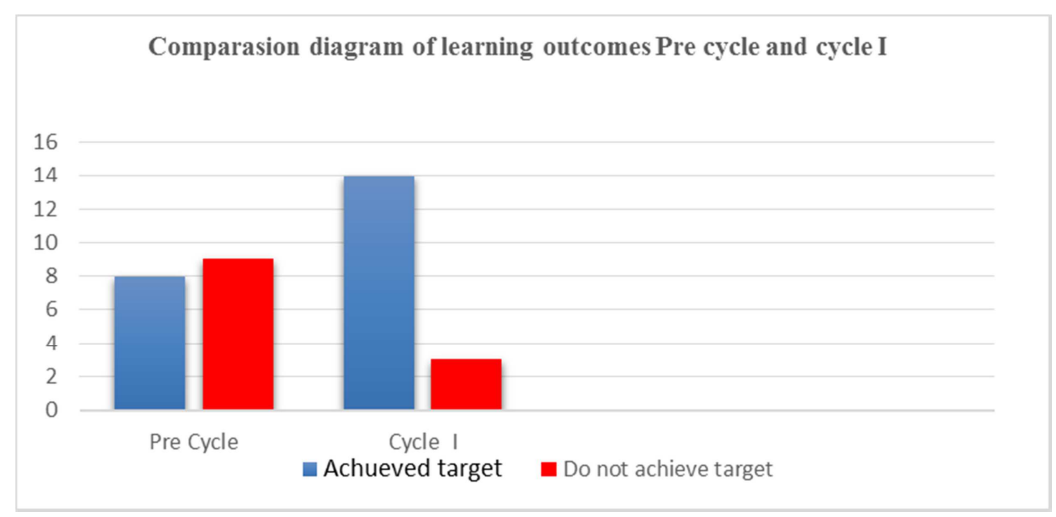

Figure 4. Graph of Comparison of Knowledge Aspects of Students on Cycle I and II.

In the second cycle the percentage of classical completeness increased to $88.4 \%$ with students completing as many as 15 students. Student learning outcomes in cycle one to cycle two increase and meet the criteria for success indicators that are set at a minimum of $85 \%$ and based on the CTM set by the school, namely $\geq 70$. Thus, the learning outcomes of students in learning mathematics students of class VI SD Lab. School FIP-UMJ have been achieved.

\section{Conclusion}

The application of the Survey, Question, Read, Reflect, Recite, Review (SQ4R) models is carried out on Mathematics subjects in the sixth grade of SD Lab. School FIP-UMJ. The SQ4R model is effectively used for mathematics because it can improve the learning outcomes of mathematics in grade VI of SD Lab. School FIP-UMJ.

The completeness of mathematical learning outcomes from a classical basis increases in each cycle, in the first cycle is $82.35 \%$ of 17 students and in the second cycle becomes $88.24 \% 17$ students. On the indicators of the success of mathematics learning outcomes, this study has been successful. In mathematics learning outcomes, the classical completeness determined is $85 \%$ of students experience an increase in mathematics learning outcomes.

\section{References}

[1] Esah, Siti. Sugiyono, Suryani. "Application of the in thematic approach improve learning activities students in 1st grade of SD 3 Siantan, Kalimantan Barat, Indonesia", August, 18, 2019. http://jurnal.untan.ac.id/index.php/jpdpb/article/download/484 $7 / 4924$.

[2] Okoro, C. O. and Okoro, C. U. "Teachers' Understanding And Use Of Thematic Approach In Teaching And Learning Of Social Studies In Rivers State', International Journal of
Education, Learning and Development Vol. 4, No. 3, pp. 6469, April 2016. August, 18, 2019. http://www.eajournals.org/wp-content/uploads/Teachers---Understanding-and-Use-of-Thematic-Approach-in-Teachingand-Learning-of-Social-Studies-in-Rivers-State1.pdf.

[3] OECD. 2018. PISA 2015 Results in Focus. August, 24, 2019. http://www.oecd.org/pisa/pisa-2015-results-in-focus.pdf.

[4] Mullis, Ina V. S. et. al. 2012, "PIRLS 2011: International Results in Reading. International Association for the Evaluation of Educational Achievement (IEA), Boston, USA. August, 25, 2019. https://timssandpirls.bc.edu/pirls2011/downloads/P11_IR_Full Book.pdf.

[5] Mullis, Ina V. S. et. al. 2017. "PIRL 2016: Internastional Results in Reading". International Association for the Evaluation of Educational Achievement (IEA): Boston, USA. August, 25, 2019. http://pirls2016.org/wpcontent/uploads/structure/CompletePDF/P16-PIRLSInternational-Results-in-Reading.pdf.

[6] Başar, Murat and Mehmet Gürbüz. 2017. "Effect of the SQ4R Technique on the Reading Comprehension of Elementary School 4th Grade Elementary School Students", International Journal of Instruction, April 2017, Vol. 10, No. 2. August 25, 2019. https://files.eric.ed.gov/fulltext/EJ1138366.pdf.

[7] Khusniyah, Nurul Lailatul; Rasyid, Yumna; Lustyantie, Ninuk. 2017. "Improving English Reading Comprehension Ability through Survey, Questions, Read, Record, Recite, Review Strategy (SQ4R)". English Language Teaching; Vol. 10, No. 12; 2017. August, 25, 2019. http://www.ccsenet.org/journal/index.php/elt/article/view/719 07.

[8] Arikunto, Suharsimi 2010. Prosedur Penelitian Suatu pendekatan Praktek. Jakarta: Rineka Cipta.

[9] Aqib, Zainal. (2010). Penelitian Tindakan Kelas. Bandung: Yrama Widya. Indonesia.

[10] Aris, Shoimin. (2014). 68 Model Pembelajaran Inovatif dalam Kurukulum 2013. Yogyakarta: Ar-Ruzz Media. Indonesia. 